\title{
Orientalism Revisited in the Chinese Context
}

\author{
Zhang Pinggong \\ The Faculty of English Language and Culture, Center for Foreign Literary and Cultural Research, \\ Guangdong University of Foreign Studies, China
}

Received August 20, 2019; Revised September 29, 2019; Accepted October 8, 2019

Copyright $\bigcirc 2019$ by authors, all rights reserved. Authors agree that this article remains permanently open access under the terms of the Creative Commons Attribution License 4.0 International License

\begin{abstract}
In his cardinal work, Orientalism, the Western Conception of the Orient and other works, Edward Said reconfigures the historical construction of European and Euro-American discourses about Near-East civilizations, cultures and peoples. By defining the "Oriental" study as discourse, it can be examined within the power structure of hierarchies. Said's repeated utilization of Foucault's theory about the relationship between power and discourse led him to an examination of the cultural imperialism. With abundant references and illustrations, he has demonstrated how Orientalism was created alongside the European cultural penetration into the lands of the "Other" and how it was justified by various disciplines and practices. Scholars in China have now criticized the ideology of Orientalism and offered their unique reflections on the subject matter in the contemporary time.
\end{abstract}

Keywords Orientalism, Discourse, Power, Criticism, Chinese Context

\section{Introduction}

Edward Said is most widely known for his tireless representations on behalf of the cause of the Palestinian people. His writings span the areas of literary criticism, politics and music. Because of his Arabic family background, a childhood spent in Palestine and Egypt and his subsequent emigration to the USA he generally restricts his focus to an examination of American, English and French imperialism and literature of the cultures of the Near East and Palestine, leaving scanty attention to China

Said's cardinal work, Orientalism, the Western Conception of the Orient (1978), falls into two halves: the first part concerned with the scope of the thought and action covered by the word Orientalism through European concrete experiences of and with Near Orient, Islam, and Arabs. The invention of the Orient by Europe, and its construction as a representation are in the foreground; the second part is about the time when this representation and academic knowledge that was manipulated around it, became an instrument in the service of colonial power. Throughout the book, Said makes a series of judgment, according to which each writer is identified in the process of intellectual hierarchy with the West above the East.

In the book, Said interprets Orientalism in a number of ways. An orientalist can be a practitioner who makes systematic study of or teaches the Orient; Orientalism may be an ideology based on ontological and epistemological distinction made between the East and the West. Many literary figures, philosophers, cultural theorists have accepted this distinction as the standard for their literary creations and social and political descriptions; Orientalism can be discussed and analyzed as an instrumental system for treating the Orient in various ways, namely, "making statements about it, authorizing views of it, describing it, teaching it and above all, ruling over it" (1978:43).

\section{Articulating Orientalism}

Said reconfigures the historical construction of European and Euro-American discourses about Near-East civilizations, cultures and peoples. By defining such "Oriental" study as discourse, it can be understood and examined within the power structure of hierarchies. Alison Brown explains that "[a] discourse is a system of rules that regulating the flow of power it and produce it" (Brown, 2000:30). The European and American discourse of Orientalism, Said maintains, enables "the enormous systematic discipline by which European culture was able to manage-even produce - the Orient politically, sociologically, militarily, ideologically, scientifically, and imaginatively during the post-Enlightenment period". The primary argument centers around the power relationships of such discourses relative to political and cultural agendas. In actual fact, no Western discourse, whether literary or scientific, about a nation, culture or people can be inert within the context of imperialism and colonization because all participants maintain a vested interest in how the cultures of the East and Near East come to be defined. Thus, 
Said argues, "the history of Orientalism has both an internal consistency and a highly articulated set of relationships to the dominant culture surrounding it". Literary and historical texts are constructed within these political contexts, creating a discourse about the East as the cultural "Other". Said's repeated utilization of Foucault's critical concept about the relationship between power and discourse led him to an examination of the relationships between discourse and imperialism. Because of his Arabic heritage, a childhood spent in Palestine and Egypt and his subsequent emigration to the USA he generally restricts his focus to an examination of Western cultural and literary imperialism. As we know, Said borrows significantly from Foucault who exposes the shifts in the structure of knowledge that enabled the transition from Renaissanc (both positive and juridical) which serves a function of promoting interests in a battle of power and desires (31). When one is aware of the configuration of power in the discourse, one sees the restrictions of it, that is "which discourses are allowed and which are not, who gets to own e and Classical thought to Modern culture, which, through disciplines such as political science and philology, first created Man as both a subject and object of knowledge. Foucault calls this history of the human sciences an archaeology, a term borrowed from Kant in order to define a "history of that which renders necessary a certain form of thought". In many works of his, Foucault addresses the theoretical relation of knowledge and history, focusing in particular on the way knowledge is ordered and used in discourse. Foucault employs the method of archaeology to exhume what he terms "the archive", the historical law which governs the relation of discourses, their emergence, transformation, and disappearances (1976:34). The method enables the exposition of the rules which regulate statements, and following this, the conditions under which certain forms of knowledge become possible.

The experimental and oppositional nature of Foucault's work has always directed and Informed debates in the areas of cultural theory and criticism. His accounts inspired a post-structuralist approach to literary and historical studies. These involved rereading literary texts in terms of the circuits of power within which they were transacted. Said's work exemplifies this approach. He uses the Foucauldian method in reading Western classical canons as discourse that simultaneously mimics and inscribes sovereign power.

In line of Foucault's thought, Said believes Orientalism is not only an academic subject that teaches knowledge on the Orient, but also a style of thought that draws a clear distinction and an opposing but no less enduring Western essence" (1978: 356). Epistemologically speaking it is a self-containing, self-reinforcing essentialism that hides historical changes, in which "objects are what they are because they are what they are, for once, for all time" ( 70). The language of Orientalism is "a form of radical realism" that the words Orientalists employ to describe their subjects are considered to "have acquired, and more simply to be, reality" (72).

To get a philosophical taste of Said's Orientalism, it's helpful to have a look at his critique as he is highly influenced by Foucault's epistemology. Foucault holds the epistemological view that "there is no absolute knowledge nor is there absolute truth" (Brown, 21), which means there are no facts apart from interpretations. From this standpoint, Said proposes it's wrong of Orientalists to hold an essentialist view on the Orient. Foucault argues that "the concept of 'man' is an invention", compared with the older invention of the human soul (Brown 22). For him, there is no unified knowing subject but a constructed "I". The right question to know oneself is not to ask "who or what is the thing that knows?" but "what stuff am I made of?" Said holds a similar view in the sense that he proposes that "the Orient is an idea that has a history and a tradition of thought imagery, and vocabulary that have given it reality and presence in and for the West" (5). The Orient is a social construct, just like Foucault's idea of human construct.

Another dimension in the schematic of Foucault's epistemology is power/knowledge. He argues that "there is no truth that is not in the struggle of power relations" (Brown 30). He holds that every society has a regime of truth. It is by this regime of truth to determine "which discourses are allowed, and which are not" and "who gets to own it and produce it" (Brown 30). So, when Said emphasizes that it's power which intertwines with knowledge that demands attention and study if one desires to understand the Oriental ideas, cultures, and histories, one understands that this idea has its roots in the creative work of Foucault. Said also remarks that "the relationship between Occident and Orient is a relationship of power, of domination, of varying degrees of a complex hegemony" (5).

Said gives an example of Flaubert's encounter with an Egyptian courtesan to illustrate this point. He analyzes the reason why the woman becomes a model of the Oriental image from two perspectives. One is the knowledge/power perspective. For Said, it is Flaubert's equipment of strength and power in relation to the woman that allows him to tell the reader about her Orientalness. To leave women silent is an exclusion rule of Orientalist discourse at work. One reason why a woman never speaks of herself is because her chance to speak has been left out by the male power. Another reason is in relation to self/other and man/woman confrontation. In defining himself as the norm or homo sapiens, Flaubert had created a type of Oriental woman. As a representative of the West, the white male author becomes the norm; he had created and eternalized the Orientalness of the Egyptian woman, the representative of the Orient. Just as she is the Other of Flaubert, the Orient is also the Other of the West. Said has long before observed the self/other confrontation as model of East/Wes. In the the introduction of Orientalism Said comments that "the Orient is ... one of Europe's deepest and most recurring images of the Other... the Orient has helped to define 
Europe (or the West) as its contrasting image, idea, personality, experience" (2).

Luce Irigaray in her famous work This Sex Which Is Not One (1981) discusses the reasons and consequences of women being defined as the "Other" in the hope that women shall get rid of the obstacles constructed to inhibit their freedom. She discovers that there is no such thing as the fixed femininity, and that there is no essence that would define women. Said's Orientalism has similar ideas to that of Irigaray in that he launches fierce attacks on the "doctrines of European superiority, various kinds of racism, imperialism" which hold "dogmatic views of 'the Oriental' as a kind of ideal and unchanging abstractions" (8). He is aware that the task of ideological emancipation is more difficult than the already achieved liberation movements in the former colonies.

Said borrows the crucial conception "hegemony" from Antonio Gramsci (1971). As a Marxist intellectual, Gramsci wanted to find out why there was no revolution in the most advanced capitalist countries. He argued that the bourgeoisie in capitalist societies maintained its dominant position, not so much through a coercive state apparatus, but through a diffuse series of relationships, institutions, ideas and values that were coextensive with civil society. Not only the state but also the Church, schools, universities, private associations, scientific circles, and cultural and moral values, could all be seen as constructing a bourgeois hegemony - a general ideological domination that permeated society, and relied not on the exercise of force but on the everyday interactions, as well as the participation and consent, of people in civil society. In this situation, the working class without sufficient capital to combat with the cultural hegemony of bourgeoisie, had no choices but to identify their own good with the good of the bourgeoisie and even helped to maintain the status quo rather than revolting.

Said is not a Marxist. He doesn't fight for a communist future, but he sees the people in the Orient to be analogous to the proletariat in such ways: they are economically, politically and culturally oppressed groups in the hands of cultural hegemony; both of them are the Other to that of whiteness and the bourgeoisie; they accept the dominant group's values and norms as their own without realizing that they are only constructs to serve the interests of the ruling class. The idea of Western cultures superior to all the non-European cultures is popular at home and abroad.

Supported by abundant references and illustrations, Said demonstrated how Orientalism was created alongside the European penetration into the lands of "Other" and how it was nurtured and "proved" by various disciplines such as history, anthropology, philosophy, literature, etc. Referring to the invisible divide of Occident and Orient, Said remarks,

"As a department of thought and expertise Orientalism of course refers to several overlapping domains: firstly, the changing historical and cultural relationship between
Europe and Asia, a relationship with a 4000 year old history; secondly, the scientific discipline in the West according to which beginning in the early nineteenth century one specialized in the study of various Oriental cultures and traditions; and, thirdly, the ideological suppositions, images and fantasies about a currently important and politically urgent region of the world called the Orient. The relatively common denominator between these three aspects of Orientalism is the line separating Occident from Orient and this, I have argued, is less a fact of nature than it is a fact of human production, which I have called imaginative geography . "(1978:14)

It is considered that the division is not static or unchanging between Orient and Occident. Thought in a sense the divide is not quite realistic, it is certainly not fictional. In Orientalism, Said emphatically treats the reconstruction of European and Euro-American discourse about civilization, cultures and peoples in some eastern countries, by redefining such "Oriental" studies against the background of Western imperialism. However, no Western discourse, literary or political, about a nation, culture and people can be at the passive end within the context of imperialism and colonization because all participants maintain a cultural sovereignty, to a certain extent. As remarked by Mao Zedong, wherever there is oppression there is resistance. For Said, "the history of Orientalism has both an internal consistency and a highly articulated set of relationships to the dominant culture surrounding it". Literary and historical texts are constructed within these political contexts, creating a discourse about the East as the cultural difference. Commenting on Oriental history, Said thinks that Oriental history for Hegel, for Marx, later for Burkhardt, Nietzsche, Spengler, and other major philosophers of history, was useful in portraying a region of great age and what had to be left behind. Literary historians have further noted in all sorts of aesthetic writings and plastic portrayals that a trajectory of "Westering", found for example in Keats and Holderlin, customarily saw the Orient as ceding its historical preeminence and importance to the world spirit moving westwards away from Asia and towards Europe (1978:17).

In discussing about the hegemonic canonization of Western literature, particularly about literary texts by Shakespeare, Said remarks,

"Each age, for instance, re-interprets Shakespeare, not because Shakespeare changes, but because, despite the existence of numerous and reliable editions of Shakespeare, there is no such fixed and non-trivial object as Shakespeare independent of his editors, the actors who played his roles, the translators who put him in other languages, the hundreds of millions of readers who have read him or watched performances of his plays since the late sixteenth century. On the other hand, it is too much to say that Shakespeare has no independent existence at all, and that he is completely reconstituted 
every time someone reads, acts, or writes about him. In fact Shakespeare leads an institutional or cultural life that among other things has guaranteed his eminence as a great poet, his authorship of thirty-odd plays, his extraordinary canonical powers in the West. The point I am making here is a rudimentary one: that even so relatively inert an object as a literary text is commonly supposed to gain some of its identity from its historical moment interacting with the attentions, judgments, scholarship and performances of its readers."'(1978:16)

However, due to the unbalance of cultural exchange and tilted flux of occidental culture, the spread of Western canons has more been experienced in the Orient. The canonization and wide recognition of Oriental literature have been confronted many "natural" obstacles. As Said realistically admitted, "I discovered, this privilege was rarely allowed the Orient, the Arabs, or Islam."(16) .

Surveying Orientalism, the essential argument in the book is that the discourse of Orientalism can create not only knowledge but also the very reality which they appear to describe - political and cultural power of the discourse. On the one hand, Said suggests that Orientalism consists of a representation, a European representation of the Orient that is far from being accurate or objective about the Orient, while on the other hand he argues that the knowledge of "Orient" could be put in the service of colonial conquest, of occupation and administration. According to Said,

"Orientalism, therefore, is not airy European fantasy about the Orient, but a created body of theory and practice in which, for many generations, there has been a considerable material investment. Continued investment made Orientalism as a system of knowledge about the Orient, an accepted grid for filtering through the Orient into Western consciousness, just as that same investment multiplied - indeed, made truly productive - the statements proliferating out from Orientalism into the general culture. " ( 67)

It is proper to say that Orientalism initiates a new kind of study of colonialism and postcolonialism. Said maintains that representations of the "Orient" in European literary texts, travelogues and other writings contributed to the creation of a dichotomy between Europe and its "Other", a dichotomy that was central to the creation of Euro-centralism as well as to the maintenance and extension of European hegemony in other lands. Said presents that this dichotomy or opposition is crucial to the self-establishment of Europe: if colonized people are irrational, Europeans are rational; if the former are barbaric, sensual, and lazy, Europe is civilized, with its sexual appetites under control and its dominant ethic of diligence; if the Orient is static, Europe can be seen as developing and marching ahead; the Orient has to be feminine so that Europe can be masculine. This dialectic between self and other, derived in part from Derrida's deconstruction, has been greatly influential in subsequent studies of colonial discourse. Some critics have traced it as informing colonial attitudes towards Africans, Native Americans, and other non-European peoples. Further, this dichotomy can lead to cultural bias in that instead of "seeking truth from fact" (Deng) and "harmony allowing diversity" "qiu tong cun yi" (Confucius). The result is usually to polarize the distinction - the Oriental becomes more Oriental, the Westerner more Western - and thus to limit the human contact and cross-cultural exchanges between different cultures, traditions, and societies.

\section{Criticisms}

Practically, in doing criticisms of Orientalism, the practitioner should be prepared to cross boundaries of knowledge, for the simple fact that Orietalism and its critique involve necessary acquaintance of "a plurality of terrains, multiple experiences and different constituencies" (1978:25) in the East and West. A strong sense of history and dialectical materialism remain functional for a sound interpretation of cross-disciplinary endeavors by Oriental and Occidental scholars and critics. Keen interventionism and commitment is required in order that the dismantling of dominant systems could be possible. Besides, some strategic methods such as mutual siege, war of maneuver and war of position deem to be usefully reflective in locating a study context and engaging criticism.

It would be significant to take notice of disputes as well as criticisms on Said's work from numerous commentators. Some criticize Orientalism for adapting a view of colonial power as all pervasive, for he claims to have based much of his work in Orientalism on the theoretical framework by Foucault and has found it useful here to employ his notion of a discourse, as described by him in The Archaeology of Knowledge and in Discipline and Punish, to identify Orientalism. Foucault suggests in his works that power manifests itself not in a downward flow from the top of the social hierarchy to those below but extends itself in a capillary fashion. He also discusses how dominant structures legitimize themselves by allowing a controlled space for dissidence - resistance, in this view, is produced and then inoculated against by those in power (1976). Following Foucault, Said tries to connect individual authors to structures of thought and to the workings of power. He further connects specific discourses and their distributions to the agents and institutions of colonialism. Consequently, he brings together a large number of representative writers, statesmen, political thinkers, philologists and philosophers who contributed to the Orientalism as an institution which then provided the scale by which the "Orient" would be considered and weighted; but equally these consideration and measurement in turn governed these ways of knowing, studying, believing and writing the "Orient". Therefore, knowledge about and power over colonized lands is related together. Several 
other recurring critiques focus on the "binary opposition model", "exclusive concentration on canonical Western literary texts", "neglect of the self-representation of the colonized", "static model of colonial relations" and so forth. Despite all these sharp criticisms, some scholars nevertheless acknowledged that Said's project inspired and coincided with widespread attempts to write "histories from below" or "recover" the experiences of those who have been somehow "hidden from history".

In recognizing Said's central contribution to the large body of knowledge on Orientalism and its critique, we should take into consideration many other impulses and works by other cultural thinkers and theorists. In Orientalism and After (1993)Said himself gives generously a list of such multiple writers and writings. Linda Nochlin's experimental studies on the 19th century Orientalist ideology as working within major art historical contexts; The great attempts of Hanna Batatu in his immense re-structuring of the terrain of the modern Arab state's political behavior; Raymond Williams' talented and systematic treatment of such essential concepts as structures of feeling, communities of knowledge, dominant, residual and emergent cultures, subculture and regional culture; Talal Asad's account of anthropological analysis about the works of mayor theorists, as well as his own contributions in the field; Eric Hobsbawm's reformulation of "the invention of tradition" and other related practices studied by other historians as an important reference system both of the historian's craft and of the invention of new emergent nations; the work produced in re-examination of Japanese, Indian and Chinese culture by the group around Ranajit Guha (Subaltern Studies), the representatives of which being Masao Miyoshi, Eqbal Ahmad, Tariq Ali, Romila Thapar, Gayatri Spivak, and younger scholars 1ike Homi Bhabha and Partha Mitter; the freshly imaginative reconsideration by Arab literary critics, the Fusoul and Mawakif group, Elias Khouri, Kamal Abu Deeb, Mohammad Bannis, and others. Their academic purpose is to redefine and invigorate the reified classical structures of Arabic. Literary efforts, and as a parallel to those above, some creative works of Juan Goytisolo and Salman Rushdie whose fictions and criticisms are expressively written against the cultural stereotypes and representations commanding the field. Further, They should also be included the pioneering efforts of the Bulletin of Concerned Asian Scholars, such as American Sinologist (Benjamin Schwartz) and Ideologist (Ainslee Embree) who have reflected seriously upon what the critique of Orientalism means for their fields; Still further, there is the critical project carried out by Noam Chomsky in political and historical fields, an example of independent radicalism and uncompromising severity; or in literary theory, the powerful theoretical articulations of a social, revolutionary definitions of canon privilege and institution by Fredric Jameson, Richard Ohmann work; Richard Poirier's revisionary Emersonian perspectives formulated in the critique of contemporary technological and imaginative, as well as cultural ideologies; and so forth (1980:24-25). The above-mentioned is significantly regarded as nothing less than innovative types of knowledge, new directions of humanistic ideology, new patterns of theory. Along with Said, they have provided new horizons for critical understanding of world society and human culture. The scholarship of Orientalism as well as its critique, in a long run, will envisage a complicated landscape and require prolonged dedication by practitioners in the lands of their creation and development.

\section{Chinese Context}

In his work Edward Said has opposed to the essentialist approach of an Orientalist, who consciously or unconsciously supports the existence of constant Oriental conditions and an "enduring Western essence" (Zhou, 2012:45). This essentialism is to see things as isolated, static and one-sided. It's by no means objective. In the Western context, the image of contemporary China is still a construct of the Other, a cultural image that always appears to be different from the West. It reflects defects in contrast with certain Western ideas, achievements, values and beliefs. This constructed image of China can be glamorized to express the Westerners' desire and imagination, although it may also be demonized to reveal their fear and anxiety. In actual fact, the Chinese conditions are only one of the many different and contradictory representations of the nation and they ought to be regarded with a dialect attitude.

China boosts its long history, and its rich and varied historical narratives reflect its progress and development in all walks of life. In modern times the country has been keeping pace with the developmental trends of the world. Ever since the founding the first Republic by Dr. Sun Yat-sen, the country has merged itself into the process of modernity. By the turn of 21 st century, the four modernizations of China concerning industry, agriculture, science and technology, and national defense have materialized to a great extent, with its achievement barely visible in the West. Most of Western observers show a welcome attitude to the rising China, and some have now treated the country not as a third world country but a modern nation, much the same as any nation state in the West.

However, those with the ideology of Orientalism think differently about China's history, believing the history featured with "stillness due to a lack of trajectory and progress" (Hesseler, 2006:3). In his recently published book, the American writer said, "in the Western traditional view of the Chinese past, there is no equivalent of the fall of Rome, no Renaissance, no Enlightenment. Instead, emperor succeeds emperor, and dynasty follows dynasty" (Ibid). The writer also equates Chinese history to China's 
rural areas being monotonous, flat, and poor. There is no change in terms of the scenery. But it is known to all that China has been through historic ups and downs as it does today. It is unfair to negate and exclude violently the basic knowledge of Chinese history. With study of many present Orientalist texts, oral and written, it is easy to see that the ahistorical China has much to do with the persistent biased Western stance on China than it does with the actualities of China. Again, it is an inauthentic construct that exists in and for the West. One should get an opportunity to see the actualities of China, to listen to the voices of its people that are hidden from the Orientalist hegemony, and the right to question some of Orientalists' implicit assumptions on China, and to give a proper answer to the question if the Republic is a mere repetition of the previous dynasties.

Said emphasizes in his work that Orientalism is a closed system in which objects are what they are because they are what they are, for once and for all time (70). The idea of the "authoritarian" China with scanty press democracy in the West is illustrative. There has been a striking difference between China and the West in terms of freedom of expression. It is believed by many in the West that China lacks freedom of the press, which is due to the governmental control. Often cited accusations are the official blocking of certain websites, the state censorship and constrains of reports on "sensitive issues" or investigating journalism. As ideology of Orientalism has strongly manifested in the China-related topics, it implicitly strengthens the divide between China and the West. In the Chinese context it has become hard to avoid the hostile implications of so-called "democracy" in journalistic life of locality. The non-democratic categorization has become instrumental to formulate a distinction between China and the West. The result is a polarization of the distinction - the West becomes more Western, and China more Chinese. The natural deduction will be if one thinks critically, he will certainly question the authenticity of broadcasting and communication from China. Consequently, China is being put in an negative situation with its lack of media rationality and press freedom.

It is commonly believed in the West that China has no freedom of religion (Grayson, 2004: 20). Certain Orientalists have been arrogant and condescending enough when they claimed that there are only five religions (Buddhism, Taoism, Islam, Catholicism, and Protestantism) in China and any attempt to have a new beliefs system would be tantamount to challenging the government (Hesseler, 2006:124). Further, the government of China would be quite alert whenever there emerges a local cult with many believers. It is being critical of religion has practically directed the masses to believing in such semi-faiths as "materialism and nationalism". One of consequences of indulging in Orientalist representation of the local cult is in fact an indifference towards the suffering of numerous sick practitioners who have repeatedly refused to receive medical treatment. A negative image of Chinese government can be subject to false such accusations and condemnations from the Western Orientalists. Furthermore, because Orientalism is a closed, self-containing and self-reinforcing system, it excludes any different voices that might negate or dismiss the "wrongdoings" by Chinese government.

Market economy during the reform period in China has been growing rapidly, which catches the attention in the West. This is often regarded by some Orientalists there that the driving force of today's China's economy is "pragmatism" (Hesseler). Specifically, when pragmatism takes an upper hand the divide between the realistic and the speculative blurs. It becomes convenient for individuals to cut corners even to break law to get things done. The Westerners taking an essential Orientalist approach to China have tried to make sense of it by attributing the phenomenon to "a lack of a rational climate" in the country (Hesseler,2006:129). Unfortunately the country as a whole is thus Otherized with an unhealthy economy when it is placed in the Western context of sound economy and structuation of management. Orientalism has successfully rewritten modern-day China into an inferior country, with an abundance of artificial services and merchandise. The Orientalists assume a fundamental difference between the East and the West, with a superior position over the East. The comparison has become polarization of the two, lacking in an adequate and fair appraisal of economic reform and its huge impact in China.

The world has entered the era of globalization, which keeps pace with the notion of postmodernity or "late modernity" in Giddens's words (1990). The impact of theories of globalization and postmodernist thinking, for instance, is great and far-reaching in that the discourse of globalisation offers a new way to view the discourse of Orientalism. In Chinese context, globalisation is a remarkable opportunity to update the basic questions concerning cultural and literary traditions and emerging cultural trends. In the local cultural field, there have been more changes than alterations concerning the "classical", the "mainstream" and popular cultures with a result that a general blurring appears among them (Wang, 2008). Specifically, the proponents of global and postmodern theme detect a major shift in the cultural landscape in which such symbolic hierarchies as Oriental and Occidental culture are deconstructed and a more global, world democratic impulse becomes manifest. The blurring of traditional divide between serious culture and popular culture becomes obvious. Comparative literature, cultural study, Internet and postmodernism are drawing more attention in China's academia.

To some extent, the Western and Chinese cultures are balanced by the level of participation, inclusion and exclusion of ones over the others. Against the background of globalization, the logical concepts of economic mechanisms, such as 'the winner is the best', 'the survival 
of the fittest' and 'natural selection and ruthless elimination', are not only applied effectively in global economy, but also in the new approach of Orientalism, specifically concerning identity formation and construction. Some identities are weakened and excluded while other identities are developed and strengthened. In some cases, "the whole new identities could even be created out of hybridisation" (Hall, 2003:124). Meanwhile, cultural mix for its own part, has served to increase the range of sources and resources available for identity construction, allowing for the production of multiple identities in the context of a world society.

Cultural identity concerns the confluence of global flow in terms of oriental and occidental culture. The global trends and local variations place a great strain on older concepts of a national and regional culture. As Rajchman said, "A global media culture provides new sources for identity formation that redefine gender, fantasies and new cultural experiences (2005:6). These lead to the fragmentation of traditional identities, subjectivities and the construction of new cultural forms. Obviously, the intersection of the global and the local is producing new matrixes to legitimise the production of hybrid identities regardless of East or West. In other words, the global permeates the local and new configurations emerge that synthesise both poles, creating 'contradictory forces of neocolonization and resistance, global homogenisation and new local hybrid forms and identities'(Yu, 2013). Although global forces can be oppressive and erode cultural traditions and identities they can also provide new method to rework one's identity and can make people well equipped to create more new ones.

Therefore, cultural development in the East and West in the times of globalization will be constructed in the process of meeting, mixing, confirming and supplementing of different culture norms, leaving old-fashioned Orientalism to the least significance. With the influence of the globalisation of cultures and the formation of a new world system, China is witnessing a "cultural movement" characterized by one 'fever' after another. Against the background of global capitalism, the above mentioned logical concepts of economic mechanism are not only applied effectively in economic activities, but also in cultural development. The hegemony of Western culture may still be influential, but the emerging local popular culture identities have managed to make a strong presence on the global stage. More and more people have changed their attitudes towards popular culture with the result that the theory and practice of Western cultural studies have recently become a fashionable interdisciplinary inquiry, a much debatable enterprise.

Since global elements have entered the country, imported Western theories and practices are welcomed. Not only are they discussed in a wide range of academic fields, but the practice of the theories has the effect of directing the practitioners towards what are perceived to be significant changes in artistic and cultural identities, methods of signification and modes of orientation in society and the people's life. Different from the former representation of Orientalism, the current Chinese discourse of modern culture is essentially co-operative but sometimes contradictory with the country's development. As a local identification of global meaning, it articulates both an anxiety over the full-blown absorption of China into the Western "world-system" and desires for intervention and resistance. Internationally, with the criticism of Western cultural hegemony, the balance of the global power is dramatically changed. But, due to political reasons, the discourse of the Cold War continues with a shift towards China (Wang, 2009). In this respect, some are trying to foster an Orientalist image of China which can be seen as resistance to globalisation though the represented image is not quite appealing to the general public. True to its name, modern China remains a socialist country despite its special characteristics. Therefore, China's ideological and political identity as a third-world country, the theory of "Socialism with Chinese Characteristics", the revolutionary traditions and the socialist spiritual civilisation, have to be recognised and considered within the context of globalisation and identity construction of the country. In economic field, the adoption of the State policy of economic reform and opening to the outside world, has been proved fruitful in many ways. Over the past decades, China has achieved progress attracting global attention. Foreign observers comment that China, "after several decades of self-imposed separation from the world economy... become an immensely significant regional and global player" (Dicken, 2006:139).

\section{Conclusions}

China has engaged itself in economic reform and involved itself in the process of globalization, but its ideological and political identity as a third-world, socialist country remains. Marxism with Chinese modifications is the guiding theory for the "initial stage of socialism". To challenge such "main theme" or "master narrative" is by no means an easy task despite the current distrust of all master narratives in postmodernist endeavors. In the contemporary period, the policies of reform can be said to have moved constantly in two directions. On the one hand, they turn against traditional Orientalism as an ideology for change. On the other hand, they look back to the past with ambivalence and even nostalgia. The recent "cultural fever" was indirectly fueled by an impassioned interest in Western theories and methodologies. Western theories and methodologies were carefully and critically studied, including the discourse of Orientalism. It is obvious that changing geographies, particularly the new forces of globalization that are now shaping our times and the global themes are significant for the cultural development in 
China. It is in this global context that we can understand critically the discourse of Orientalism. It is also in this context that the mutual implementation instead of conventional hegemony is now becoming more important than ever in this globalization era.

Numerous critics and writers have attached much emphasis on Orientalism and regarded it as a pioneer work with a universal appeal. They feel that some Euro-American and the "Third World" scholars in residence of the West and China have voiced strongly and criticized Western cultural hegemony, thus making a unique contribution to literary studies and cultural criticism. As a path-breaking work in the field of colonial and post-colonial studies, Said's Orientalism is capable of challenging fundamentally peoples' ways of viewing the world. Therefore, the significance of Said's work is great and the new interpretation of Orientalism in the Chinese context is significant.

\section{REFERENCES}

[1] Brown, A. Leigh. On Foucault: A Critical Introduction (2000). Wadsworth.

[2] Dicken, Peter. Global Shift: Transforming the World Economy (2006). London: Sage Publications.

[3] Foucault, Michel. The Order of Things: An Archaeology of the Human Sciences (1976), London: Fontana Press.

[4] Giddens, Anthony. The Consequences of Modernity (1990). Cambridge: Polity Press.

[5] Gramsci, Antonio. Selections from the Prison Notebooks of Antonio Gramsci (1971) Vintage Books, 1971

[6] Grayson, Benson Lee, ed. The American Image of China. New York: Frederick Ungar Publishing Co, 2004.

[7] Irigaray, Luce. This Sex Which Is Not One, Translated by Claudia Reeder, in New Faminisms, ed. Elaine Marks and Isabelle de Courtivron (1981). New York: Cornell University Press.

[8] Hall, Stuart. The Question of Cultural Identity (2003). Milton Keynes: Open University Press.

[9] Hessler, Peter. Oracle Bones: A Journey Through Time in China. New York: HarperCollins Publishers, 2006.

[10] Rajchman, John. The Identity in Question (2005). Ed. London: Routledge

[11] Said, Edward. Orientalism, the Western Conception of the Orient (1978). Vintage Books

[12] Said, Edward. "Orientalism and After - An Interview with Edward Said " Radical Philosophy (1993), Spring.

[13] Williams, Raymond. Keywords: A Vocabulary of Culture and Society (1976). London: Fontana Press.

[14] Wang, Ning . Globalisation and Postcolonial Criticism
(2008). Beijing: Central Compilation \& Translation Press.

[15] Wang, Jisi . 'Comments on Debate on the "Civilisation Clash', Studies on International Cultural Theories (2009). Beijing: Chinese Social Sciences Press

[16] Yu, Keping. Globalisation and Its Contradictory Interpretations (2013), ed. Beijing: Central Compilation \& Translation Press

[17] Zhou, Ning, Western Images of China. Beijing: Peking University Press, 2012. 